\title{
Atatürk Üniversitesi Merkezi Açık-Yeşil Alandaki Fiziki Değişim Memnuniyetinin Belirlenmesi
}

\author{
Ayşegül AKSU' ${ }^{1}$, Hasan YILMAZ
}

ÖZET: Üniversiteler eğitim ve öğretim kurumları olmalarının yanı sıra aynı zamanda sosyo-ekonomik ve kültürel bir dizi işlevleri yerine getirmektedir. Üniversite yerleşkelerinde uygun peyzaj tasarımlarıyla başta öğrenciler olmak üzere eğitim ve öğretim kadrosuna yaşanabilir dış mekan oluşturulması oldukça önemlidir. Özelikle Erzurum gibi soğuk iklim şartlarına sahip yerleşkelerde kışları uzun geçmesinden dolayı kısa olan konforlu iklim aralıklarında dış mekanda zaman geçirmeye karşı olan özlem daha fazla olmaktadır. Bu çalışma Atatürk Üniversitesi Yerleşkesinde, merkezi açık yeşil alanda peyzaj tasarımı yapılan alanın yapım öncesi ve yapım sonrası kullanıcı memnuniyetini ortaya koymak amacıyla yapılmıştır. Bu amaçla, öğrenciler, öğretim üyeleri ve memurlarla farklı dönemlerde 2 anket çalışması yapılmıştır. Anket sonuçlarına göre peyzaj tasarımı yapılmadan önce kullanıcıların alanı görsel (74.2) ve bitkisel tasarım yönünden zayıf buldukları (71.6) saptanmıştır. Bu nedenlerle, bu alanın öncelikli kullanıcıları olan öğrenci ve üniversite çalışanlarına daha konforlu hizmet sunacak bir duruma getirecek bir tasarım yapılmasına ihtiyaç olduğu sonucuna varılmıştır. Nitekim peyzaj tasarım uygulaması sonrası yapılan anketlerle kullanıcı memnuniyetinin arttığı, katılımcıların \%75.6'sının alanda yapılan tasarımın gerekli olduğuna inandıkları ve tasarım yapılan bu alanın üniversiteye prestij kazandırdığı belirlenmiş̧ir.

Anahtar Kelimeler: Kampus planlama, öğrenci memnuniyeti, üniversite yerleşkesi, yerleşke planlama

\section{Measuring the Satisfaction Regarding Physical Renovation of the Central Open-Green Square in Atatürk University}

\begin{abstract}
Universities perform a series of socio-economic and cultural functions in addition to being educational institutions. It is of great importance to provide a livable outdoor for academic staff and particularly for students through suitable landscape designs in university campuses. In campuses, particularly those which take place in cities with cold climate such as Erzurum, people long for spending time outside at short intervals of comfortable seasons since winters last for long. This study was carried out in order to reveal user satisfaction for pre-design and post-design of open green field at Atatürk University where landscape design was performed. Therefore, two questionnaires were conducted to students, academic staff, and officers at different time. According to the results, it was pointed out that users found the field as being poor in terms of visuality (74.2) and botanical design (71.6) before landscape design. In this sense, it was concluded that it is really needed such a design that will offer more comfortable service for the students and academic staff who are the primary users of this field. In fact, through the questionnaire carried out after landscape design, it was demonstrated that user satisfaction has arisen, $75.6 \%$ of the participants believe that landscape design is of necessity, and the field which was designed has brought prestige for the university.
\end{abstract}

Keywords: Campus planning, settlement design, student satisfaction, university campus

Ayşegül AKSU (0000-0002-6720-0256), Hasan YILMAZ (0000-0003-3768-4760), Atatürk Üniversitesi, Mimarlık ve Tasarım Fakültesi,

Peyzaj Mimarlığı, Erzurum, Türkiye

Sorumlu yazar/Corresponding Author: Ayşegül AKSU, aysegulaaksu@ hotmail.com

* Bu çalışma Ayşegül AKSU’nun Yüksek Lisans tezinin bir bölümüdür. 


\section{GíRIŞ}

Üniversiteler ülkelerin sosyal, kültürel ve ekonomik yönden kalkınabilmesi, gelişebilmesi, ilerleyebilmesi ve ülkeler arası ilişkilerde geri kalmaması açısından büyük öneme sahiptir (Irgatoğlu, 2011).

Öğrencilerin mesleki, sosyal, psikolojik açıdan yetişmelerini ve olgunlaşmalarını sağlamayı hedefleyen üniversitelerin, hem fiziksel, hem akademik hem de sosyal kalitesi fazlasıyla önem taşımaktadır. Bütün kullanıcıların bir arada zaman geçirebilmeleri için memnun edici biçimde planlanması, tasarlanması ve uygulanması gerekmektedir (Yazıc1, 2007). Yerleşke planlaması yapılırken birçok faktör göz önünde bulundurulmalıdır. Yerleşkelerin fiziksel planlamasındaki planlama ve tasarım ilkelerinin incelendiği birçok çalışma yapılmış ve benzer yaklaşımlarda bulunulmuştur (Benli, 1998; Sönmez, 2003; Oruçkaptan, 2003; Bodur ve ark., 2005).

Açık-yeşil alanların önemi her geçen gün daha da artmaktadır. Dolayısıyla ağaçlar kentsel peyzajın bir parçası olarak görülmekte, kentsel mekanlarda ağaçların varlığı yerleşimlere üniversal kent özelliği katmaktadır. Yerleşke planlamasında açık yeşil alanlar; ekolojik, ekonomik, estetik, rekreasyonel ve psikolojik bir çok fonksiyonları yerine getirirler (Y1lmaz ve Irmak, 2012).

Üniversite yerleşkeleri kapladıkları alan bakımından kent ekolojisini önemli ölçüde etkilemekte ve mikroklima oluşturma açısından büyük önem taşımaktadır. $\mathrm{Bu}$ sebeple bitkilendirme çalışmalarına özen gösterilmelidir (Irgatoğlu, 2011).

Ülkemizde üniversite yerleşke planlaması üzerine çok sayıda çalışma yapılmış olup (Benli, 1998; Çınar, 1998; Sönmez, 2003; Çorbacı ve ark., 2005; Y1lmaz ve Yılmaz, 2005; Tolon, 2006; Özer, 2008; Erdoğan, 2009; Irgatoğlu, 2011; Koç, 2011; Tetik, 2013), bu çalışmalarda optimum fiziki planlamanın gerekliliğ̣i üzerinde durulmuştur. Yurtdışında ise yerleşke fiziki planlamasına yönelik çok sayıda çalışma yapılmıştır. (Abu-Ghazzeh,
1999; Hall, 2006; Silverman, 2008, Lau and Yang, 2009; Asadi-Shekari et al., 2014; Lau et al., 2014; Matloob et al., 2014; Türk, 2015).

Üniversite yerleşkelerinin fiziki planlamasına ek olarak alan kullanıcıların taleplerini içeren yerli ve yabancı çalışmalar yürütülmüştür (Yıldızoğlu, 2006; Yazıc1, 2007; Ayvac1, 2009; Ertekin ve Çorbac1, 2010; Hipp et al., 2015; Hossini et al., 2015; Sedaghatnia et al., 2015).

Atatürk Üniversitesi Yerleşkesinde; Atatürk Üniversitesi Yerleşkesinin planlamasında yapılan hatalar ve çözüm yolları (Kaplan, 1996), Pinus slyvestris L. ve Populus nigra'nın gürülttüyü azaltma üzerine etkisi (Özer ve ark., 2008), Atatürk Üniversitesi öğrencilerinin rekreasyonel eğilimleri (Turgut ve ark., 2009), Atatürk Üniversitesi yerleşkesinde görsel kalite analizi (Demirci, 2010), Atatürk Üniversitesi Yerleşkesinde insanların bilinç ve duyarlılık düzeylerinin belirlenmesi (Demircioğlu ve ark., 2011), Atatürk Üniversitesi yerleşkesi ve yerleşke bitkilendirmesi (Yılmaz ve Irmak, 2012) ile ilgili çalışmalar yapılmıştır.

\section{Çalışmanın amacı}

Çalışmada Atatürk Üniversitesi merkez yerleşkesinin; alan kullanıcı memnuniyetini ortaya koymak, öncelikle çok sayıda fakülte ve hizmet binasının bulunduğu merkez yerleşkenin mevcut rekreasyonel talepleri yerine getirme potansiyelini ve mevcut sorunlarını tespit etmek, bu alanda yapılan peyzaj tasarımının kullanıcı memnuniyetini belirlemek ve ortaya çıkan sonuçların yerleşke planlama ve tasarımına veri oluşturması amaçlanmıştır.

\section{MATERYAL VE YÖNTEM}

\section{Materyal}

Çalışmanın materyalini Atatürk Üniversitesi Mühendislik Fakültesi ile Eğitim Fakülteleri arasında bulunan açık alan oluşturmaktadır (Şekil 1).

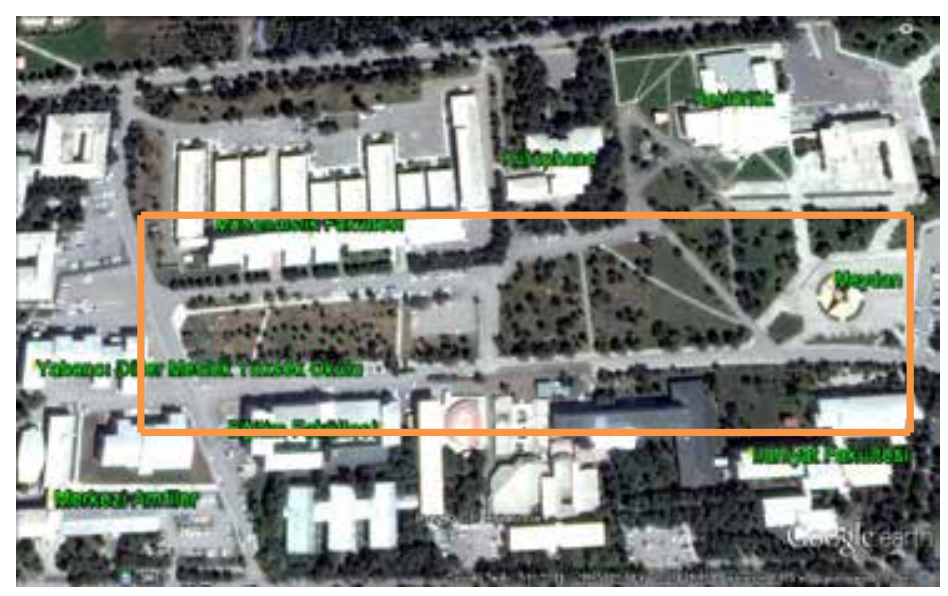

Şekil 1. Çalışma alanının uydu görüntüsü 
Tasarım alanının peyzaj düzenlemesi yapılmadan önceki mevcut durumunu, saat kulesi, tören alanı, yürüme yolu, otopark, araç yolu, çim yüzeyler ve rastgele dikilen ağaçlar oluşturmaktadır (Şekil 2).

Çalışma alanı için 2014 yılında Prof. Dr. Hasan Yılmaz tarafından peyzaj tasarım projesi hazırlanmıştır. Projenin ihalesi Atatürk Üniversite Yap1 İşleri ve Teknik Daire Başkanlığı tarafından yapılmış, proje uygulaması ise Eylül 2014 tarihinde genel sekreterlik tarafından başlatılmıştır. Kasım 2015 tarihinde ise proje uygulaması tamamlanmıştır.

Yapılan peyzaj tasarımı sonucu alanda; sert yüzeyler/ teras, otopark, yol sirkülasyonları, bitkisel tasarım uygulamaları, oturma birimleri (açık ve kapalı), 2 adet informal havuz, küçük amfi, aydınlatma üniteleri, donatılar (çöp kutusu, bank, çiçek kasası), 1adet küçük kafeterya mevcuttur (Şekil 2).
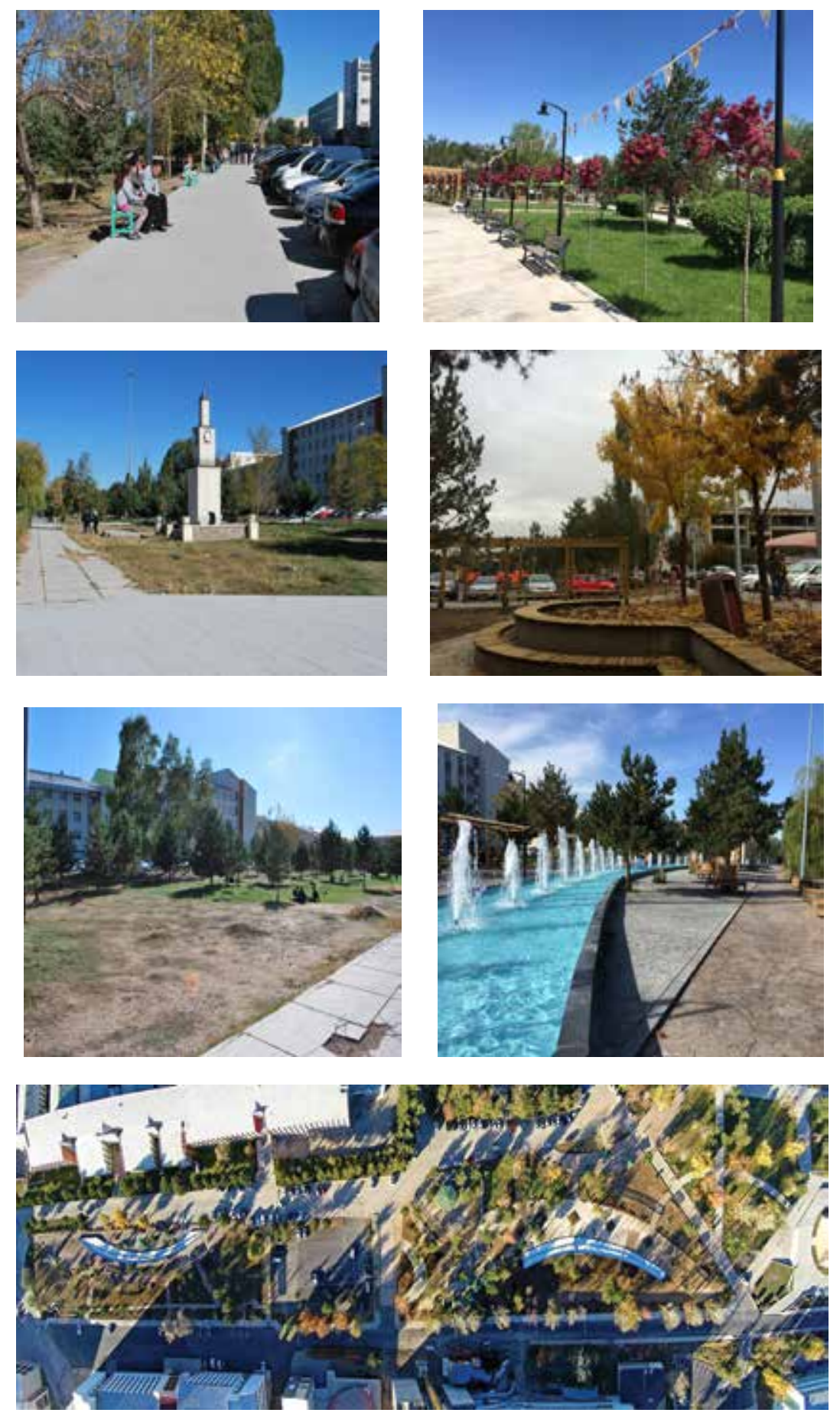

Şekil 2. Alanın peyzaj tasarımı yapılmadan önceki ve sonraki mevcut durumu 


\section{Yöntem}

Çalışma alanı olan üniversite merkez açık yeşil alanda peyzaj tasarım projesi uygulaması yapılmadan önceki ve sonraki durumunun kullanıcı memnuniyeti bakımından karşılaştırması yapılmıştır. Öğrencilerle, öğretim görevlileri ve memurlarla farklı dönemlerde 2 anket çalışması ve bir ara değerlendirme yapılmıştır. Anketler; alanın birincil kullanıcı olmaları nedeniyle, alanda ve etrafındaki fakültelerde uygulanmıştır.

Oluşturulan standart anket soruları bireysel özellikler ile bireylerin alandan memnuniyet ve beklentilerini belirlemeye yönelik likert tipi derecelendirmeli sorular, çoktan seçmeli ve açık uçlu soruları içermektedir. Uygulanan anketlerdeki likert tipi beşli değerlendirmenin aralık sınırlarının hesaplanması aşağıda verilmiştir.

Anketlerin aralık sınırlarının hesaplanması: seçenek sayıs $=5$, aralı sayıs $1=5-1=4$, aralı katsayıs $=4: 5=0.80$, ortalama karşılaştırmalar esas olmak üzere 1'den 5'e kadar olan beğeni sınırlarına göre değerlendirme yapılmıştır.

Alan içinde ve çevresinde 1. Anket döneminde 317 ve 2. anket döneminde 120 adet olmak üzere toplam anket sayısı 437'dir.. Anket sayıları tesadüfi örnekleme yöntemi ile belirlenmiştir.

Peyzaj tasarım süreci ve uygulama öncesinde alanın mevcut durumu hakkındaki görüşleri ve alanın tasarım gerekliliğini belirlemek amacıyla karşılıklı olarak bire bir anket uygulanmıştır (Şekil 3). Daha sonra uygulama çalışmaları sırasında bitkisel tasarım uygulamaları başlamadan önce, sadece sert zemin uygulamas1 bitirildikten sonra yapım aşamasındaki uygulamaların mevcut durumu ile ilgili memnuniyeti ve beklentiyi belirlemek amacıyla alanda öğrenci, öğretim görevlisi, memur ayrımı gözetmeksizin 30 kişi ile karşılıklı soru cevap şeklinde sözlü bir ara değerlendirme yapılmıştır. Peyzaj tasarım projesi uygulaması sonrasında alanın son durumunun kullanıcı memnuniyetini ortaya koymak amacıyla 2. anket çalışması yapılmıştır.
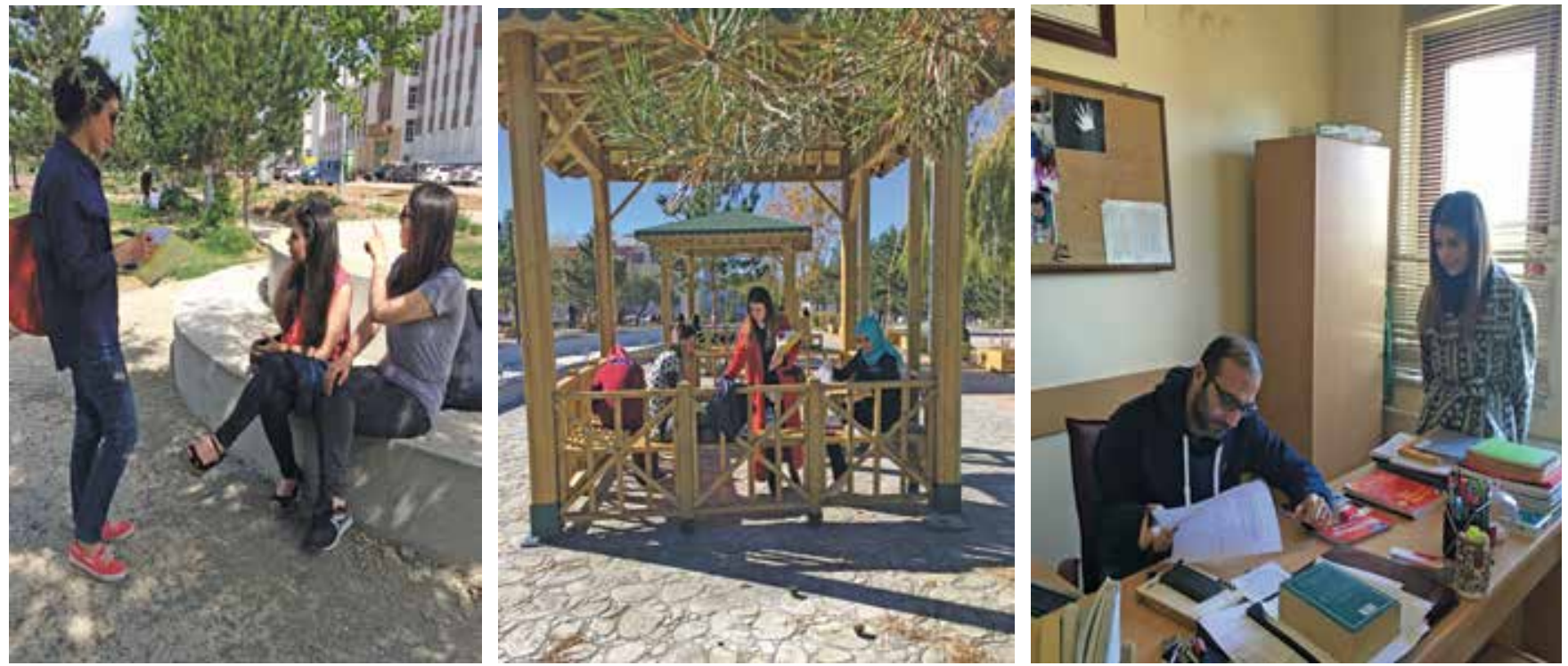

Şekil 3. Alanda yapılan anket çalışması

$\mathrm{Bu}$ anketlerin değerlendirilmesinde istatistiki analizler SPSS for Windows 22.00 istatistik programı ile yapılmıştır. Elde edilen verilerin analizinde aritmetik ortalama, standart sapma, ki-kare testi, tek yönlü varyans analizi, LSD post hoc testi ve $\mathrm{t}$ testi olarak 6 farklı istatistiksel analiz kullanılmıştır.

\section{BULGULAR VE TARTIŞMA}

Ülkelerin sosyal, kültürel ve ekonomik açıdan gelişebilmesi ve ülkelerarası ilişkilerde geri kalınmaması için üniversiteler çok önemlidir. Ülkenin ihtiyaç duyduğu hizmet alanlarında uzman işgücü yetiştiren üniversiteler, toplumun ihtiyacına uygun yeni 
bilgiyi üretip, bunu gelecek kuşaklara aktarırken aynı zamanda toplumun ufkunu açarak sürekli gelişmesini sağlamaktadırlar (Karakaş, 1999). Yurtdışındaki (Cornel, Harvard, Cambridge, Oxford) ve ülkemizdeki (ODTÜ, Bilkent, Hacettepe, Boğaziçi) üniversitelerde de görüldüğü gibi fakülteler arasında kalan merkezi yeşil alanlar sadece yeşil alan olarak değil, öğrenci ve üniversite çalışanlarının vakitlerinin çoğunu geçirdiği, yoğun okul temposuna ara verip, ders aralarında sıkışık öğrenci kantinleri yerine açık havada nefes aldığı, psikolojik olarak rahatladığı, rekreasyonel aktivitelerde bulunduğu alanlar olarak kullanılmaktadır.

Üniversite yerleşkelerinde açık ve yeşil alanların genelde bir park şeklinde planlanması, gerek akademisyenler ve gerekse öğrencilerin huzurlu bir ortamda bulunması açısından oldukça önemlidir. $\mathrm{Bu}$ durum eğitim ve ögretimin kalitesine olumlu olarak yansır (Çorbacı ve ark., 2005).

Dış mekanlarda bir çok peyzaj düzenleme çalışmaları yapılmaktadır. Fakat yapılan düzenlemelerin beğenilip beğenilmediği kontrol edilmemektedir. $\mathrm{Bu}$ çalışmada ise Atatürk Üniversitesi yerleşkesindeki merkezi açık yeşil alanda öncelikle kullanıcıların rekreasyonel gereksinimleri 1 . anket ile ortaya koyulmuş, sorunları tespit ettikten sonra bu doğrultuda hazırlanarak merkez açık yeşil alanda uygulamaya koyulan peyzaj tasarım projesinin yapımı aşamasında ara bir değerlendirme ve proje tamamlandiktan sonra da kullanıcı memnuniyetini bilimsel yolla test etmek amacıyla 2. anket uygulanarak otokontrol yapılmıştır.

Çalışma alanı üniversitenin en merkezi yerinde bulunmaktadır. Üniversite yerleşkesinin yaklaşık \%7080 'i bu alanın etrafında konumlandığı için alanın yoğun kullanımı karşılayabilecek şekilde tasarlanması hedef kitle olan; öğrenci , öğretim görevlisi, memur ve lojman dokusuna kazandırılması yerleşke açısından büyük önem taşımaktadır.

Alanın mevcut durumu ve yapilacak yeni tasarımıyla ilgili soruları içeren 1. anket toplam 317 adet olmak üzere öğretim üyesi, memur ve öğrencilere yapılmıştır. Anket verilerine göre katılımcıların görsel (74.2) ve bitkisel tasarımı (71.6), oturma elemanlarını (87.4) ve çöp kutusu (57.7) gibi donatı elemanlarını yetersiz bulduğu, alanı en çok öğlen arası (\%36.9), ders aralarında (\%30.9) kullandığı, alanı en çok bölümlerine ve yurtlarına yakın olduğu için (\%34.4) tercih ettikleri, mevcut durumda en çok yeşil alanlar
(\%33.8) ve çim yüzeylerden (\%24.3) memnun olduğu, oturma birimlerinin azlığ $1 \% 26.2)$ ve kirlilik-çöplerden (\%21.1) memnun olmadığı, çalışma alanının yeni tasarımında en çok olmasını istedikleri donatıların açık oturma alanları (\%88.6) ve geniş çim yüzeyler $(\% 85.8)$ olduğu saptanmıştır.

Akademisyen, öğrenci ve memurların birinci ankete verdiği cevaplar açısından farklar incelendiğinde; alanı tercih etmelerinin en önemli sebebi açısından aralarındaki farklar anlamlı bulunmuştur $\left(\chi^{2=} 21.661\right.$ $\mathrm{p}=0.002$ ). "Başka alternatif olmadı̆̆ 1 için" seçeneği akademisyen ve memurlara göre öğrenciler tarafindan daha fazla seçilmiştir..

Çalışma alanı tam bitirilmeden, bitkisel tasarım uygulamaları başlamadan önce mevcut durumun mekan kullanıcıları üzerindeki etkilerini ortaya koymak amacıyla, alana gidilmiş ve bire bir görüşme yapılmıştır. Öğretim üyesi ya da öğrenci tercihi gözetmeksizin alanda 30 kişi ile karşıllıklı olarak sözlü bir değerlendirme yapılmıştır. Görüşme yapılan kişiler genel olarak alanın proje uygulaması yapılmış halde olmasını istediklerini, üniversite yerleşkesinde yeterince çim alanın bulunduğunu, isteyenlerin bu alanları tercih edebileceğini ve bu yüzden proje alanının eskiden olduğu gibi geniş çim yüzey şeklinde kalmasının gerekmediğini aksine bu alanın birçok farklı alan kullanıma yer vermesi gerektiğini vurgulamışlardır. Alanda olması istenilen öğelerin ise; açık ve kapalı oturma alanları, kafe, bakımlı çim alanlar ve su yüzeyleri olduğu saptanmıştır. Ayrıca cevapların büyük çoğunluğu, alanda yapılacağı söylenen öğe ve tasarımların yapılıp uygulamaya geçeceği takdirde bu alanın kullanışlı, estetik ve gerekli olacağına inandıkları yönünde olmuştur.

Proje alanının yeni tasarımındaki memnuniyeti belirlemek amaciyla öğrencilere, daha sonrada öğretim üyeleri ve memurlara anket yapılmıştır. Peyzaj tasarım çalışmasında çim alanlar, bazı sınırlandırıcı elemanlar, mevsimlik çiçekler olmadan bitirilen son durumu ile ilgili olarak proje alanında 2 . anket çalışması yapılmıştır. Uygulanan toplam anket sayıs1 120'dir.

Proje alanının yeni tasarımındaki memnuniyeti belirlemek amacıyla yapılan 2.anket çalışması sonucunda; görsel tasarımın (\%52.2), oturma alanlarının (\%71.7), otoparkın (41.7), aydınlatma elemanlarının (77.5), bölümler arası yol sirkülasyonunun (\%52.2) yeterli bulunduğu saptanmıştır. Ancak bitkisel tasarım 
$\% 38$ yeterli bulunmuştur. Ayrıca katılımcıların alanı en çok ders aralarında (\%37.5), öğlen arasında (\%36.7) ve bölümlerine, yurtlarına yakın olduğu için (\%46.8) tercih ettikleri, alanda kendilerini güvende hissettiği (\%65), tasarımı yapılan alanda en çok pergola, çardaklar (\%39.2) ve su yüzeylerini (\%25.8) beğendiği, beğenilmeyen tasarımların ise bitkisel tasarım (\%25.8) ve teraslar (\%21.8) olduğu, katılımcıların alanı eski haliyle kalmasını istemediği (\%69.2), alanda tasarım yapılmasının gerekli olduğuna inandıkları (\%75.6) ve alanın üniversiteye prestij kazandırdığı $(\% 61.7)$ sonucuna varılmıştır.

Bazı oranların düşük çıkma sebepleri sıralanacak olursa, mevsim kışa denk gelmesi katılımcıları yanılgıya düşürmektedir. Serme çim uygulamasının yapılmamış olması çim alanların az, terasların ise çok fazlaymış gibi görünmesine de sebep olmaktadır. Bahar ve yaz aylarında serme çim uygulaması yapıldığında, ağaçlar yapraklanıp çiçeklendiğinde, mevsimlik çiçekler dikildiğinde, çiçek kasaları çiçeklendirildiğinde, gölge yapan ağaçlar formlarına ulaştığında, su yüzeyler aktif edildiğinde, alan içerisindeki kafeterya da öğrenciye hizmet verme derecesine geldiğinde, çevresi masa ve oturma birimleri ile donatıldığında, çöp kutuları yerleştirildiğinde kullanıcıların memnuniyet derecesinin artacağı ve daha mutlu olacağı beklenmektedir.

Ayrıca Eğitim Fakültesinin önünde uzun zamandır inşaat çalışması devam ettiği için insanlarda bir bıkkınlık oluşmuştur. $\mathrm{Bu}$ sebeple alanla ilgili bazı görüşlerin olumsuz olması normaldir.

\section{KAYNAKLAR}

Abu- Ghazzeh TM, 1999. Communicating behavioral reserch to campus design: factors affecting the perception and use of outdoor spaces at the university of Jardon. Environment and Behavior, 31(6): 764-804.

Asadi-Shekari Z, Moeinaddini M, Shah MZ, 2014. A pedestrian level of service method for evaluating and promoting walking facilities on campus streets. Procedia- Social and Behavioral Sciences, 38: 175-193.

Ayvacı G, 2009. Üniversite kampüslerindeki dış mekan tasarımında kullanıcı gereksinimlerinin belirlenmesine yönelik bir araştırma. İTÜ Fen Bilimleri Enst., (Basılmamış) Yüksek Lisans Tezi, 174s.

Benli AC, 1998. A comparative study for university campus planning. Dokuz Eylül Üniv. Fen Bilimleri Enst., (Baılmamış) Yüksek Lisans Tezi, 166s.
Akademisyen, öğrenci ve memurların ikinci ankete verdiği cevaplar açısından farklar incelendiğinde; öğrencilerin memurlara göre bitkisel tasarımı daha yetersiz bulduğu $\left(\chi^{2=} 4.091 \mathrm{p}=0.019\right)$, öğrencilerin alanı bölümlerine, yurduma vs. yakın olduğu için ve başka alternatifleri olmadığı için, akademisyenlerin ise stres attığ1 için, öğrencilerin ders aralarında, memurların öğlen arasında ve saat 5'ten sonra ise akademisyen ve memurların bu alanı daha fazla kullanmayı tercih ettikleri sonucuna varılmıştır.

Çalışma öncesi ve sonrasını temsil eden 1. ve 2. ankete verilen cevapların aritmetik ortalams1 karşılaştıııldığında; 2. anket de, görsel tasarım, bitkisel tasarım,otopark, oturma birimleri, aydınlatma elemanları yeterliliği ve insanların kendilerini güvende hissetme oranlarında artış görülmüştür.

\section{SONUÇ}

Sonuç olarak; bu alan için ortaya konan peyzaj tasarımdan öğrenci, akademisyen ve memurların memnun oldukları kanısına varılmıştır. Fakat peyzaj yaşayan bir süreçtir. Tam etkiyi ortaya koymak için zamana ihtiyaç vardır. Değişik mevsimlerde özellikle bitkisel tasarımın etkisi daha iyi ortaya çıkacağından alanla ilgili memnuniyet derecesinin artmas1 beklenmektedir. $\mathrm{Bu}$ alanda ilkbahar, sonbahar ve kış dönemlerinde de anketler yapılarak memnuniyet derecelerinin zamana bağlı olarak değişim dereceleeri ortaya konmalıdır. Ortaya çıkan sonuçlara göre alan yönetimine yön verilmelidir.

Bodur MN, Doygun H, Kuşat Gürün D, 2005. Kahramanmaraş Sütçü İmam Üniversitesİ Avşar yerleşkesinde fiziksel yapılanma çalışmalarının dünü, bugünü ve geleceği. II. Ulusal Üniversite Yerleşke Planlaması ve Çevre Düzenlemesi Çalıştayı, 9-10 Haziran 2005, Kahramanmaraş.

Çınar E, 1998. Üniversite kampüs planlaması ve tasarımı üzerine bir araştırma. İTÜ Fen Bilimleri Enst., (Basılmamış) Yüksek Lisans Tezi, 159s.

Çorbacı ÖL, Gülez S, Topay M, 2005. ZKÜ merkez kampüsü 1S1 merkezi yolu ve çevresi peyzaj ve rekreasyon projesi. ZKÜ Bartın Orman Fakültesi Dergisi, 7 (7): 24-34.

Demirci E, 2010. Atatürk üniversitesi yerleşkesinin görsel kalite yönünden değerlendirilmesi. Atatürk Üniv. Fen Bilimleri Enst.,(Basılmamış) Yüksek Lisans Tezi, 97s. 
Demircioğlu N, Y1lmaz H, Yılmaz S, 2008. Effects of snow reflected light levels on human visual comfort.Enviromental Monitoring and Assesment. Environ Monit Assess, 144: 367-375.

Demircioğlu N, Y1lmaz H, Y1lmaz S, 2011. Effects of personal characteristics on environmental awareness; a questionnaire survey with university campus people in a developing country, Turkey. Scientific Research and Essays, 6(2): 332-340.

Erdoğan M, 2009. Dünya'da ve Türkiye'de üniversite yerleşkelerinin peyzaj planlama ve tasarımında, "üniversite başarımı ve sürdürülebilirlik" ilişkisinin irdelenmesi. İTÜ Fen Bilimleri Enst., (Basılmamış) Yüksek Lisans Tezi, 75s.

Ertekin M, Çorbacı ÖL, 2010. Üniversite kampüslerinde peyzaj tasarımı, Karabük peyzaj tasarım projesi örneği. Orman Fakültesi Derg., 10(1): 55-67.

Hall DA, 2006. Participation in a campus recreation program and its effect on student retention. Recrational Sports Journal, 30: 40-45.

Hipp JA, Gulwadi GB, Alves S, Sequeira S, 2015. The relationship between perceived greenness and perceived restorativeness of university campuses and student-reported quality of life. Environment and Behavior, 48(10): 1292-1308.

Hossini SB, Azemati S, Elyasi N, Mozaffar F, 2015. The effect of the vitality level of university campuses on increasing social interaction and makin. Procedia- Social and Behavioral Sciences, 170: 225-233.

Irgatoğlu AN, 2011. Üniversite kampusları fiziksel gelişim ve tasarımı: Yozgat Bozok Üniversitesi Erdoğan Akdağ kampusu örneği. Ankara Üniv. Fen Bilimleri Enst., (Basılmamış) Yüksek Lisans Tezi, 240s.

Kaplan K, 1996. Atatürk Üniversitesi kampüsü peyzaj planlamasında ortaya çıkan problemler ve çözüm yolları üzerine bir araştırma. Atatürk Üniv. Fen Bilimleri Enst., (Basılmamış) Yüksek Lisans Tezi, $105 \mathrm{~s}$.

Karakaş B, 1999. Üniversite kampuslerinin fiziksel gelişim planı hazırlama süreci ve Bartın orman fakültesinin bu bağlamda idelenmesi. ZKÜ. Fen Bilimleri Enst., (Baılmamış) Yüksek Lisans Tezi, 202s.

Koç A, 2011. Iğdır Üniversitesi yerkeşkesinin peyzaj planlama ve tasarım ilkelerinin belirlenmesi. Atatürk Üniv. Fen Bilimleri Enst., (Basılmamış) Yüksek Lisans Tezi,126s.

Lau S, Yang F, 2009. Introducing healing gardens into a compact universty campus. Design Natural Space to Create Healthy and Sustainable Campuses. Landscape Research, 34 (1): 5581.

Lau SSY, Gau Z, Liu Y, 2014. Healthy campus by open space design. Approaches and Guidelines. Frontiers of Architectural Research, 3:452-467.

Matloob, FA, Sulaiman AB, Ali TH, Shamsuddin S, Mardyya WN, 2014. Sustaining campuses through phsysical character- the role of landscape. Procedia- Social and Behavioral Sciences, 140:282-290.
Oruçkaptan A, 2003. TMMOB Peyzaj Mimarları Odası, Üniversite Yerleşke Planlaması ve Çevre Düzenlemesi I. Ulusal Çalıştayı, 16-17-18.Ekim 2003, Malatya.

Özer M, 2008. Üniversite alanlarının kentsel tasarım bağlamında değerlendirilmesi: Süleyman Demirel Üniversitesi (Isparta) örneklemesi. SDÜ Fen Bilimleri Enst., (Basılmamış) Yüksek Lisans Tezi, 122s.

Ozer S, Irmak MA, Y1lmaz H, 2008. Determination of roadside noise reduction effectiveness of Pinus slyvestrisL. and Populus nigra L. in Erzurum, Turkey. Environmental Monitoring and Assessment, 144 (1-3): 191-197.

Sedaghatnia S, Lamit H, Abdullah AS, 2015. Experience of social inclusion among students in University Campuses of Malaysia. Procedia- Social and Behavioral Sciences, 170: 89-98.

Silverman M, 2008. Campus security begins with caring. Chronicle of Higher Education, 54(32):51.

Sönmez H, 2003. Kentsel kamusal diş mekanlara yönelik master plan oluşturma çalışmalarının Ege Üniversitesi yerleşkesi örneğinde ortaya konması. Ege Üniv. Fen Bilimleri Enst., (Basılmamış) Yüksek Lisans Tezi, 267s.

Tetik AD, 2013. Üniversite kampüsleri tasarım kriterlerinin Türkiye'de 2006 sonrası yeni kurulan devlet üniversitelerinde irdelenmesi. Gazi Üniv. Fen Bilimleri Enst., (Basılmamış) Yüksek Lisans Tezi, 221s.

Tolon MB, 2006. Üniversite kampusları dış mekan tasarım ilkeleri ve Ankara Gölbaşı Kampusu peyzaj tasarımı. Ankara Üniv Fen Bilimleri Enst., (Basılmamış) Yüksek Lisans Tezi, 119s.

Turgut H, Yeşil P, Yılmaz S, 2009. Determining the recreational demands and tendencies of students at Atatürk University through questionnaires. Science Research and Essay, 4 (3): 152-159.

Türk YA, Sen B, Ozyavuz A, 2015. Students exploration on campus legibility. Procedia- Social and Behavioral Sciences, 197: 339347.

Yazıcı AB, 2007. Bir sosyal çevre olarak yerleşke kimliği oluşmasında donatı elemanlarının önemi: Başkent Bağlıca yerleşkesi üzerine alan çalışması. Ankara Üniv. Sosyal Bilimler Enst., (Basılmamış) Doktora Tezi, 199s.

Yıldızoğlu MZ, 2006. Üniversite yerleşkeleri fiziksel gelişim planlaması ve tasarımı: Çanakkale Onsekiz Mart Üniversitesi Terzioğlu yerleşkesi örneği. Çanakkale Onsekiz Mart Üniv. Fen Bilimleri Enst., (Basılmamış) Yüksek Lisans Tezi, 151s.

Yılmaz H, Irmak MA, 2012. Yerleşke planlamasında Bitkisel Tasarım İlkeleri; Atatürk Üniversitesi Yerleşkesi Örneği. Atatürk Üniv. Yayın No:1011, Erzurum, Türkiye. 192s.

Yılmaz S, Y1lmaz H, 2005. ABD'den örnek bir üniversite yerleşkesi; Cornell Üniversitesi. II. Ulusal Üniversite Yerleşke Planlaması ve Çevre Düzenlemesi Çalıştayı, 9-10 Haziran 2005, Kahramanmaraş. 